\title{
Decoloniality, Theology and Bodies: Tamar and Jesus as Examples of Othering and Bonding
}

\author{
Janneke Stegeman
}

\begin{abstract}
Der Beitrag, der sich weniger als exegetischer Aufsatz denn als Predigtanalyse versteht, zeigt anhand des homiletischen Umgangs mit den biblischen Figuren Jesus und Tamar, in welcher Weise koloniale Deutungsmuster in der Rezeption der Bibel bis heute nachwirken. Jesus wird seiner Geschichte als Kritiker und Opfer imperialer Gewalt zum Trotz als weißer Christus gezeichnet, der einerseits seines kritischen Potentials verlustig geht, andererseits aber herrschaftsförmig wird. Dieses Phänomen bezeichnet der Aufsatz in Anlehnung an die Bildung eines Männerbundes als ,bonding. Demgegenüber wird die in Gen $3^{8}$ dargestellte Figur der Tamar in der homiletischen Rezeption in einem Prozess des Othering als ,die Andere' konstruiert. Entgegen derjenigen Deutung, die Tamars körperliche Selbstbestimmung wahrnimmt und ihr Verhalten als einen Widerstand gegen ihren Ausschluss versteht, wird sie in den analysierten Predigten überwiegend in abwertender Weise wahrgenommen. Der Aufsatz spricht sich dafür aus, biblische Figuren gerade in ihrer subversiven Kraft wahrzunehmen, die sich nachwirkenden kolonialen Vereinnahmungen entziehen.
\end{abstract}

\section{Introduction}

One aspect of colonization is the categorization and racialization of human bodies. Western Christianity, including theology and biblical scholarship, is complicit in this colonial categorization that centres the white, heterosexual, male body. Colonial categorizations and hierarchies, such as 'race', were read into biblical texts. ${ }^{1}$ Even though we live in a postcolonial era, ${ }^{2}$

1 See for instance Daniel M. Goldberg, The Curse of Ham, Race and Slavery in Early Judaism, Christianity and Islam, Princeton 2005; Willie James Jennings, The Christian Imagination: Theology and the Origins of Race, Yale 2011.

2 I use the term postcolonial in the same sense as Kwok Pui-Lan does: postcolonial refers to "a reading strategy and discursive practice that seeks to unmask colonial epistemological 
coloniality survived colonialism. ${ }^{3}$ In many research areas, including that of theology, scholars therefore undertake the task of decolonizing their methods and knowledge. Part of this task is to understand how whiteness functions.

Decolonial approaches aim to contextualize and "provincialize" white bodies, by exposing and thus removing their claim of normativity. Fear is often part of this process, especially for white Western scholars like me: as scholars located in the normative centre of power, ${ }^{4}$ enjoying its privileges, we now discover the locatedness of our supposedly neutral methods and the contextuality of our knowledge that previously seemed to have almost universal validity.

\section{Bibles, Christianities and Colonialisms}

The West, its appropriation of the Bible and colonialism are interconnected. ${ }^{5}$ The Bible itself was written in imperial contexts; in its texts both imperial interests and resistance against imperialism are reflected and intertwined: in the Book of Jeremiah for instance, diverse Judean communities struggle for power and authority against one another in the context of Babylonian imperial dominance. ${ }^{6}$ Most biblical literature is produced within such imperial contexts. The social groups within the Israelite and Judean communities producing the biblical texts were often located in the more intellectual upper class between colony and empire. ${ }^{7}$ Accordingly, biblical texts are politically charged texts in which power is negotiated between empire and periphery and space for resistance is sought.

Theology in the Western world contributed to a narrative that legitimized systems of colonialism, using Biblical texts as a basis. Such dominant colonial lenses influenced how the Bible and Christian traditions were understood both

frameworks" in awareness that what used to be coloniality is now neocolonialism (cf. KwOK PUI-LAN, Postcolonial Imagination \& Feminist Theology, Louisville 2005, 2).

3 Nelson Maldonado-Torres, On the Coloniality of Being, in: Cultural Studies 21 (2007), 240-270, 243 .

4 In postcolonial analysis, the center stands for the groups in society that have power and discursive tools. Those in the center shape the dominant narratives of society and are able to present nuanced narratives of their identity. The identities of groups in the margins are essentialized and objectified as part of the dominant narrative. The colonial other is defined by their perceived difference from the norm and thus marginalized.

5 See for instance Michael Prior, The Bible and Colonialism: A Moral Critique, Sheffield 1999.

6 Carolyn C. Sharp, Prophecy and Ideology in Jeremiah: Struggles for Authority in the Deutero-Jeremianic Prose, New York 2003.

7 KWOK PUI-LAN, Postcolonial Imagination \& Feminist Theology, Louisville 2005, 8-9. 
among colonizers and colonized. Postcolonial biblical scholarship attempts to unmask imperial power relations within biblical narratives, and also in church and in theology, which includes biblical scholarship itself, and lastly in society. It searches for struggle and resistance in the text in appropriations and seeks to listen to subaltern voices. ${ }^{8}$

One of the decolonizing tasks undertaken by biblical scholars is to decolonize biblical bodies. Indeed, among the endless numbers of colonized bodies are also biblical bodies, figuratively speaking. ${ }^{9}$ As mentioned above, biblical interpretation played an important role in the development of Western colonial ideology. Jesus was imagined as a white male, and as such he was distributed in colonial contexts. This colonized Jesus was an agent of "othering" in the sense that he embodied an exclusive Western Christianity.

\section{$3 \quad$ Theology and Bodies}

The Latin-American theologian Marcella Althaus-Reid criticized liberation theology for not addressing human beings as sexual beings. ${ }^{10}$ Liberation theology's preferential option for the poor needed to be sexualized, according to Althaus-Reid: the male, white, heterosexual body still functioned as theology's dominant and normative body. Theology was dominated by a system of decency, or a heterosexual matrix, which is part of imperial strategies of power. ${ }^{11}$ "Decent" bodies are those bodies that are considered good and normal in a certain society, whereas the bodies that express themselves in (sexually) nonacceptable ways are "indecent". What is needed according to Althaus-Reid, is a theology that challenges "decency" as an imperial strategy.

In this paper, attentiveness to the "in/decent" is understood as a necessary element of the decolonization of biblical studies. I aim to contribute to the contextualization of biblical appropriations in my context as a Dutch white Protestant theologian by analyzing how the bodies of Tamar and Jesus are appropriated in four sermons held in Dutch Protestant churches. My point of departure in understanding biblical figures is hybridity. There is no "original

\footnotetext{
$8 \quad$ Loc.cit., 79.

9 Cf. loc.cit., 168-185, Anthony G. Reddie, Decolonizing the Body of Christ: An Initial Response, in: David Joy/Joseph Duggan (eds.), Decolonizing the Body of Christ: Theology after Theory and Empire?, New York 2012, 179-196.

10 Cf. Marcella Althaus-Reid, Indecent Theology: Theological Perversions in Sex, Gender and Politics, New York 2006, 4-6.

11 Althaus-Reid, Indecent Theology, 91.
} 
understanding" that can be claimed as "pure and foundational". ${ }^{2}$ I want to point out how our colonial heritage and our understanding of decency play a formative role.

Western colonial rule needed "othering" of people in order to legitimize colonial hierarchies..$^{13}$ Presenting non-white non-Europeans as uncivilized legitimated violence against them. The process of othering isolates a group that is constructed as different from the perceived normality and superiority of the colonizers. Examples of such constructed differences are reflected in the colonial binaries of white versus black and heterosexual versus homosexual. The process of othering rests on constructed differences and stereotypes. In practice, the others never fit neatly into the categories of imperial power. Rather, the others continually challenge rigid colonial categories simply by existing. In postcolonial approaches, the marginalized are placed in the centre, or in other words: postcolonial theology locates itself in the margins. The process of othering can be reversed by decolonial intervention that deconstructs imperial categories. For instance, an image of Jesus that was congealed ${ }^{14}$ in colonial Christianity was made fluid again as black Jesus, as transsexual Jesus, bisexual Jesus, and asexual Jesus.

Post- or decolonial theology always addresses one's own position, body, relation towards power, gender, sexuality, cultural and political framework. As white Dutch Protestants in a postcolonial society we have to become aware of how colonial categories still play a role in our appropriation of the Bible. Because of our perceived normativity, I suggest our perspective is in need of othering as a hermeneutical strategy. I refer to othering in an alternative sense

12 PUI-LAN, Imagination, 182.

13 Gayatri Spivak coined the term othering which she describes as a gendered, raced and classed discourse in which the colonial other is defined, GAYATri Chakravorty SPIVAK, the Rani of Sirmur: An Essay in Reading the Archives, in: HTh 24 (1985), 247-272. These perceived differences are objectified into otherness in order to create an in-group (the colonial center) and an out-group (the colonized). This discourse of othering legitimizes the superiority of the dominant group.

14 The term "congealing" is used by Judith Butler to describe how a framework becomes normative and seemingly normal through repetition, for instance: "gender is the repeated stylization of the body, a set of repeated acts within a highly rigid regulatory frame that congeal over time to produce the appearance of substance, of a natural sort of being" (Judith Butler, Gender Trouble: Feminism and the Subversion of Identity, New York 1990, 33). 
of "queering": for Althaus-Reid, "queer" implies a space of resistance to oppressive "normality". By incorporating biblical bodies into the colonial status quo, they were stripped from their critical potential. Othering as a hermeneutical strategy focuses on and recreates distance between a reader and a biblical figure. Such distance is necessary in a context where the biblical narrative was incorporated into a colonial narrative. "Othering" in this positive sense is the process by which white, Dutch protestant theologians like me can rediscover our non-normativity and our provinciality.

For the opposite hermeneutical strategy of incorporating biblical narratives and figures I suggest the term bonding, as in "male bonding". Male bonding usually presupposes male, heterosexual identity. Bonding focuses on and creates proximity. Bonding contributes to a homogenous, normative, unchallenged identity. The effect is that a biblical body can no longer challenge or question the normativity of the body of the reader.

\subsection{Othering and Bonding in Sermons on Tamar and Jesus}

In the following passage I analyze four sermons on the story of Tamar (Gen 38:1-30) held by reverends from different Protestant denominations in the Netherlands during the period of Advent. ${ }^{15}$ Accordingly, I observe whether or not the strategies of othering and bonding as described above are applied to the figures of Jesus and Tamar.

According to the narrative in Genesis 38 Judah, one of Jacob's sons, marries a (nameless) Canaanite woman. She gives birth to three sons. The oldest son, Er, marries Tamar, who is also a Canaanite woman. When Er dies, following the custom of the levirate marriage, Onan, Judah's second son, now marries Tamar. But Onan too dies and Judah then decides to send Tamar home under the pretext that his third son Selah is still too young to marry her. Thus, Judah marginalizes Tamar: she now is a woman without children and without a male protector in a patriarchal context. Tamar does not accept this. She dresses as a prostitute and offers her body to Judah, who has sexual intercourse with her. Tamar becomes pregnant, and Judah wants her burned when he hears the news. But Tamar took his staff and seal to prove the father's identity. Tamar gives birth to two boys, twins.

15 Rolinka Klein Kranenburg (sermon 1), Rebecca Onderstal (sermon 2), sermon 1,2 can be found online as appendices of AAFJE ROEST's bachelor thesis "Toekomst Baren" (2016), see https://dspace.library.uu.nl/handle/1874/315208 (Bijlage 3, pp. 55-58; Bijlage 7, pp. 68-71), BAS VAN DER GRAAF (sermon 3, http://bas-graafwerk.blogspot.nl/2013/12/ prekenserie-vrouwen-uit-de-stamboom-van.html), Dick DRESC HLER (sermon 4, Tamar: God laat de rode draad doorlopen, https://ickdreschler.wordpress.com/2013/12/01/ genesis-38-tamar-god-laat-de-rode-draad-doorlopen/). 
All sermons link Tamar's narrative to that of Jesus. Appropriation of Tamar's narrative is complicated by her perceived indecency. Her behaviour sits ill with traditional Protestant Christian understandings of what is decent: prostitution and having sex with the father of your deceased husbands are not. In sermon 1,2 and 4 the "problem" of Tamar's indecent behaviour is addressed as follows, "Tamar chooses sin" (sermon 4). Tamar's sinfulness is then connected to our sinfulness, and put in opposition to Jesus, who is without sin. Tamar acts "cunningly" (sermon 1). There is "something smelly" about Tamar, she "plays the whore" (sermon 2).

In the biblical narrative, Tamar is the Canaanite and female other who nevertheless takes agency in a patriarchal Israelite context. In the sermons, Tamar is othered (in the colonial sense): she is a Canaanite woman, and therefore an "outsider", from a world in which "people deny each other future" (sermon 1). According to sermon 1, because to Tamar's position as an outsider, she is able to see more clearly how the Torah of Israel "provides future". The Torah of Israel is idealized here and put in opposition to Canaanite customs. The suggestion is that contemporary Dutch society is not patriarchal. Tamar is an outsider here, but at the same time she is bonded with as a courageous figure in the lineage of Jesus.

It is through her relationship with Jesus that the sermons smoothen Tamar's "problematic behaviour": Tamar's intervention leads to the birth of two boys, which ultimately leads to the birth of Jesus. By understanding her "indecent" behaviour as a necessary part of the larger Christian narrative, it becomes acceptable. It is her proximity to Jesus that allows Tamar to be seen as "decent" enough. In sermon 4, too, the importance of the ongoing Christian narrative, culminating in the birth and life of Jesus, is underlined.

Sermon 3 also places the narrative in this larger Christian framework: because of Tamar's unconventional acts "the promises of God will be fulfilled". However, in this sermon Tamar is presented in a very positive light: she is a "strong" and "righteous" woman-Tamar is called "tsaddik", the highest distinction in the Old Testament. At the same time Tamar's "history" is characterized as "crooked". According to this reverend, the Bible "chooses the side of women" in this narrative, although elsewhere elements of patriarchy can be found. Patriarchal subordination of women still exists in Muslim societies today, the reverend adds. He also briefly discusses male violence as a problem of contemporary Dutch society. This minister explicitly mentions his own male body and relates Tamar's experiences with men to experiences of sexual violence experienced by many women in Dutch society today. This minister allows the text to ask questions about subordination of and violence against 
women, also in contemporary Dutch society. Tamar's experiences become relatable for contemporary hearers who are in a similar position.

This reverend is an exception. The biblical narrative is rather physical with its dressing up, sexual intercourse and giving birth. In the other sermons however, bodies are not mentioned. In all sermons, Tamar's body is only referred to implicitly and her sexuality is absent. The sexual act is merely suggested as a necessary step for her to have children and safeguard her future. The sermons point at Tamar's difficult position in a patriarchal society, but do not evaluate to which extent Tamar is able to make her own choices. Rather, she becomes part of a patriarchal system again, in the narrative through motherhood and in the sermons by underlining the importance of her giving birth for the larger Christian narrative. In sermon 4 especially, the value of having children is underlined. The minister sympathizes with hearers who were not able to have children.

In the four sermons, Jesus exclusively appears in a positive role. Unlike Tamar, he is "one of us" already, except that unlike the hearers Jesus is without sin. Tamar's role is ultimately instrumental to the birth of Jesus. This is presented as the central event in all sermons. Jesus "fulfils God's will appropriates all our life stories", the "crooked" story of Tamar, and ours too, in order to make us "just" in spite of our failures (sermon 3). In a sense, in sermon 3 and 4, Jesus is instrumental too, namely to the production of grace, so that the hearers are saved. Both Tamar's and Jesus' bodies perform actions that are crucial to how the community of believers position themselves. The message of sermon 2 is to "remain expectant", to "be touched by the hope that something new is possible". Sermon 1: the unstoppable thirst for justice and the courage to put one's own life at risk, of both Tamar and Jesus. Sermon 4 is the most traditional: all of this happened, so that Jesus, the Saviour, was born. Jesus came into a sinful world to save us.

\subsection{Can the Biblical Body Speak to White Bodies?}

In the analysed sermons I ascertained that the space for the figures of Tamar and Jesus to challenge, destabilize or question the narratives of the hearers is limited. The hermeneutic strategy applied to Jesus is mostly that of bonding. Only when Jesus is presented as without sin and as our saviour (sermons 3 and 4) there is a distance, but still, in his role of saviour Jesus comes so close to us that he absorbs our life stories. Even though Tamar sometimes represents the other, this hardly leads to challenging questions. Tamar is incorporated into the Christian narrative before she can become too challenging. 
The biblical scholar's task is to analyse and challenge how one's appropriations of biblical bodies are related to one's own gender, class, ethnicity and political power. The analysis of four sermons in this article indicates that more work needs to be done in order for biblical texts to be part of a post-/decolonial conversation. ${ }^{16}$ We need to make explicit whether we as readers are part of the margin or the centre, and how this connects us to margins and centres in the narrative. The narrative then becomes a point of departure for conversation, exploration and growing self-awareness.

\section{Bibliography}

\section{Primary Sources-Sermons (all in Dutch)}

Sermon 1 (Rolinka Klein Kranenburg): https://dspace.library.uu.nl/handle/1874/315208 (Bijlage 3, pp. 55-58).

Sermon 2 (REBECCA ONDERSTAL): https://dspace.library.uu.nl/handle/1874/315208 (Bijlage 7, pp. 68-71).

Sermon 3 (BAS VAN DER GRAAF): http://bas-graafwerk.blogspot.com/2013/12/ prekenserie-vrouwen-uit-de-stamboom-van.html.

Sermon 4 (Dick Dreschler): https://dickdreschler.wordpress.com/2013/12/o1/ genesis-38-tamar-god-laat-de-rode-draad-doorlopen/.

\section{Literature}

Althaus-Reid, Marcella, Indecent Theology: Theological Perversions in Sex, Gender and Politics, New York 2006.

ButLer, Judith, Gender Trouble: Feminism and the Subversion of Identity, New York 1990.

Dube, Musa M., Postcolonial Feminist Interpretation of the Bible, St. Louis 2000.

Goldberg, Daniel M., The Curse of Ham, Race and Slavery in Early Judaism, Christianity and Islam, Princeton 2005.

Jennings, Willie James, The Christian Imagination: Theology and the Origins of Race, Yale 2011.

16 For post-/decolonial perspectives on the bodies of Jesus and Tamar see for instance MUSA M. Dube, Postcolonial Feminist Interpretation of the Bible, St. Louis 200o; David Joy/ Joseph Duggan (eds.), Decolonizing the Body of Christ: Theology after Theory and Empire?, New York 2012. 
Joy, David/Joseph Duggan (eds.), Decolonizing the Body of Christ: Theology after Theory and Empire?, New York 2012.

Kwok PUi-LAN, Postcolonial Imagination \& Feminist Theology, Louisville 2005.

Maldonado-Torres, Nelson, On the Coloniality of Being: Contributions to the Development of a Concept, in: Cultural Studies 21 (2007), 240-270.

Prior, Michael, The Bible and Colonialism: A Moral Critique, Sheffield 1999.

Reddie, Anthony G., Decolonizing the Body of Christ: An Initial Response, in: David Joy/Joseph Duggan (eds.), Decolonizing the Body of Christ: Theology after Theory and Empire?, New York 2012, 179-196.

Sharp, Carolyn C., Prophecy and Ideology in Jeremiah: Struggles for Authority in the Deutero-Jeremianic Prose, New York 2003.

Spivak, Gayatri Chakravorty, The Rani of Sirmur: An Essay in Reading the Archives, in: HTh 24 (1985), 247-272. 